\title{
Intra-household decision-making, production diversity, and dietary quality: a panel data analysis of Ethiopian rural households
}

\author{
Orkhan Sariyev ${ }^{1}$ (D) $\cdot$ Tim K. Loos $^{2} \cdot$ Ling Yee Khor ${ }^{1}$ \\ Received: 18 October 2019 / Accepted: 17 August 2020 / Published online: 26 August 2020 \\ (C) The Author(s) 2020
}

\begin{abstract}
Considering that rural poor are mostly subsistence farmers, it seems plausible that production diversity could lead to better nutrition for these farmers. The association between production and dietary diversity is complex, and this complexity demands rigorous empirical analyses and more attention to gendered aspects of intra-household decision-making. We employ panel data analyses of 363 Ethiopian smallholders surveyed in 2014 and 2016 to test for this phenomenon, and to explore the association of women's participation in decision-making with both production and consumption diversity. Results show that, diversification can be a strategy to improve the diets, but only of rural poor who have limited non-farm income, who are distant to the markets and mostly subsistence oriented. Moreover, female participation in decision-making associates with higher diversity both in terms of production and consumption, but it does not modify the magnitude of the association between production and dietary diversity. Our analyses contribute to the enriching literature on the linkage between production diversification and dietary diversity. We study this complex relationship in-depth and show that the gendered aspect of intra-household decision-making is an important covariate for both production diversity and dietary quality.
\end{abstract}

Keywords Decision-making $\cdot$ Dietary diversity $\cdot$ Production diversity $\cdot$ Panel data $\cdot$ Ethiopia $\cdot$ Smallholder farmers

\section{Introduction}

Achieving zero hunger is the second goal of the Sustainable Development Goals (SDGs) of the United Nations Development Program (United Nations Development Programme 2019). Although the increase in agricultural productivity and overall economic growth have contributed to the decline in the number of undernourished people, today, more than 820 million people still experience hunger and around two billion experience moderate food insecurity. The numbers

Orkhan Sariyev

o.sariyev@uni-hohenheim.de

Tim K. Loos

tim.loos@giz.de

Ling Yee Khor

LY.Khor@uni-hohenheim.de

1 University of Hohenheim, Hans-Ruthenberg-Institute, Stuttgart, Germany

2 Deutsche Gesellschaft für Internationale Zusammenarbeit (GIZ) GmbH, Bonn, Germany are rising in the African continent. The most recent data suggest that roughly 260 million people in Africa are undernourished (FAO, IFAD, UNICEF, WFP and WHO. 2019). SubSaharan Africa is home to the poorest population in the world, many of whom experience alarmingly high nutritional deficiencies (Ahmed et al. 2007; Barrett 2010). African Union (AU) initiated African Regional Nutrition Strategy (ARNS) 2005-2015 which provided guidance to many African countries to improve nutrition. ARNS 2015-2025 is an extension of the earlier strategy which also emphasize the importance of nutrition sensitive agricultural transformation that provides food security for poor (AU 2015).

Considering a high dependency of rural poor on agriculture, nutrition-sensitive agricultural research and programs have gained significant attention in the region. Considering that rural poor are mostly subsistence oriented, encouraging diversified farm production is perceived to be a promising strategy to achieve better dietary outcomes. Against this background, the association between production diversity and dietary diversity is tested in different settings. Recent impact evaluation studies show that nutrition sensitive agricultural programs have generally yielded positive outcomes, and observational studies have mostly identified production diversity and livestock ownership 
as most important determinants of dietary diversity (Ruel et al. 2018). Many studies report a positive association between onfarm diversification and the dietary status of rural households (Ecker 2018; Islam et al. 2018; Jones et al. 2014; Koppmair et al. 2016; Pellegrini and Tasciotti 2014), while some find mixed results depending on the country and measurement of dietary and diversification indicators (Sibhatu et al. 2015; Sibhatu and Qaim 2018a). When significant, the low magnitude of the reported association in these studies creates doubt if the strategy of increasing dietary diversity through production diversification would be effective. A review of literature predominantly from Sub-Saharan Africa by Jones (2017a) indicates existing positive association between agricultural diversification and dietary diversity. However, the review also highlights that based on the reported magnitudes of association between production diversity and dietary diversity, it would require unrealistic increases in the number of species produced to have a meaningful change in dietary diversity. Sibhatu and Qaim (2018b) have very similar conclusion. They report that an average farmer in Sub-Saharan Africa would need to grow nine additional species to increase dietary diversity by one food group. Other factors like access to market and alternative livelihoods like non-farm income are observed to have larger effects than production diversification in many cases (Dixon et al. 2001; Jones 2017a; Koppmair et al. 2016; Sibhatu et al. 2015). Moreover, the association between production diversity and dietary diversity is complex. Production diversity interacts with factors like availability of non-farm income, access to markets, and commercialization of the households. Therefore, the significance and magnitude of the association are situation specific (Islam et al. 2018; Sibhatu et al. 2015). We look into this interaction in detail and estimate marginal effects of production diversity at different specifications. In this paper, we mainly address the question of complex association between production and dietary diversity. We adopt and employ an approach by Brambor et al. (2006) that can also be followed in future studies that aim to investigate the association between production and dietary diversity in detail.

Production diversity is an ex-ante risk management strategy for risk-averse rural households (Just and Candler 1985). In Ethiopia, conservation of landraces and crop biodiversity in the fields can mitigate negative impacts of different weather associated shocks, promote productivity improvements, and contribute to food security (Di Falco and Chavas 2009). Like dietary diversity, farm production diversity is determined by various demographic, socioeconomic and infrastructural factors like household demographics, wealth, access to market and other infrastructural and institutional services. A factor, gender, is linked to various aspects of rural livelihoods like adoption of agricultural technologies and practices (Fisher and Carr 2015; Ndiritu et al. 2014), investment of generated income and credit (Carter et al. 2017; Garikipati 2008) and food security (Galiè et al. 2019; Larson et al. 2019; Malapit et al. 2019; Sariyev et al. 2020; Sraboni et al. 2014). Moreover, recent observational studies that investigate agriculture and nutrition linkage find that livestock ownership and production diversity are prominent for dietary diversity, and women's empowerment can be an important mediator (Ruel et al. 2018). As both diversification of production and diets are decisions that are outcomes of household decision-making processes in which household members belonging to different gender and sociodemographic background may intensively participate, it is reasonable to investigate the effect of female participation in decision-making on both production and dietary diversity. To the best of our knowledge, this covariate has been widely overlooked in similar studies with the exception of Jones et al. (2014) who only investigate if the gender of the head and women's control of income modify the association between farm and dietary diversity. ARNS 2015 2025 highlights the importance of empowering women - increasing their nutrition knowledge, productive skills, control of productive resources, and participation in intra-household decision-making - to achieve sustainable nutrition outcomes (AU 2015).

Considering the debatable link between production diversity and dietary diversity, the complexity of this association, and gendered preferences in decision-making that are likely to affect both livelihood outcomes, there are two objectives that we pursue in this study. The first objective is to estimate the association between production diversification and household dietary diversity, and rigorously investigate the significance and magnitude of the association in various settings. Secondly, we examine the association of women's participation in decision-making with both production diversification and household dietary diversity, respectively. We contribute to the growing literature on the association between production diversity and dietary diversity; we explore the complexity of the association in detail, and investigate the importance of gendered aspects of intra-household decision-making with regard to both livelihood outcomes.

The paper proceeds with detailed information of the materials employed and methods used in section 2 ; section 3 presents, interprets and discusses regression results; section 4 concludes the paper and highlights policy implications of the findings.

\section{Data and methods}

\subsection{Data}

The analyses are built on data from 363 Ethiopian households surveyed in 2014 and 2016. This is a randomly chosen subsample of farmers from a nationally representative survey that was conducted by the International Food Policy Research 
Institute (IFPRI) for the Ethiopian Agricultural Transformation Agency (ATA) in 2012. This survey had a sample size of 3000 households in four main regions of Ethiopia. ${ }^{1}$ Due to administrative and logistical constraints, our surveyed households were randomly chosen from the list of ATA survey farmers (i.e. 480 farmers) located in a radius of circa 150-200 km around the town of Hawassa. The area covers large parts of Southern Nations, Nationalities, and Peoples' (SNNP) and Oromia regions. Considering the diversity of agro-ecological zones, production systems, infrastructural endowments and market accessibility in the surveyed area, we believe that the findings from the sub-sample are suitable for drawing some wider conclusions. Although we have a balanced panel of 390 households, we limit the analyses to those 363 households where both genders are present, i.e. the cases where bargaining between genders may actually occur.

Enumeration was done by a team of trained enumerators using computer assisted personal interviews (CAPI). The questionnaire covered a wide array of household livelihood related characteristics including infrastructural and institutional access, adoption of agricultural technologies, land endowment, crop production, asset ownership, food consumption and so forth. Regarding decision-making, considering that households make various decisions that affect their livelihoods, households were asked questions regarding their decision-making behavior in each relevant questionnaire section. In the following subsections, we describe the methods used to extract our main variables from the most relevant sections of questionnaire. We conclude this section by describing the econometric estimation strategies used in the analyses, the results of which are reported and discussed in the following section.

\subsection{Production diversity measures}

We use three measures to capture production diversity and to check for the robustness of its association with dietary diversity. The first measure of production diversity used in the analyses is the Simpson's Index of Diversification (SID) that captures both crop species richness and evenness in the farmer's cultivated area. SID is calculated as:

$S I D=1-\sum_{i=1}^{n} S_{i}^{2}$

where

$S_{i}={ }^{a h} / A_{h}$

where $a_{i h}$ reflects the area dedicated to the production of crop $i$ and $A_{h}$ is the total cultivated area by household $h$. Thus, $S_{i}$ captures the proportion of area dedicated to the cultivation of crop $i$ in the total cropped area. SID ranges between zero and

\footnotetext{
${ }^{1}$ See Sawyer and Minot (2013) for more information regarding 2012 ATA baseline survey.
}

one, with zero indicating that the household has no crop diversification and one meaning that the household has a completely diversified crop production in terms of richness and evenness. For example, a household that dedicates $75 \%$ of its cultivated area to one crop and $25 \%$ to another crop will have a lower SID score than another household who dedicates $50 \%$ to each crop, although they both grow the same number of crop species. In this measure of production diversity, we also capture the evenness concept of diversification. Thus, species grown in small plots like kitchen gardens are unlikely to lead to a meaningful change in the index. SID has been employed in recent similar studies (Jones et al. 2014; Linderhof et al. 2016; MofyaMukuka and Hichaambwa 2018).

The second measure is generated by simply counting the number of different crop and livestock species produced by the farmers in the past 12 months before the interview. This measure has been widely used to investigate the association between production and dietary diversity in several studies (Islam et al. 2018; Jones et al. 2014; Sibhatu et al. 2015; Sibhatu and Qaim 2018a). It has its limitations, as its dietary perspective is limited in cases where households produce inedible crops like cotton or where many crops that belong to the same food group are produced. That is why, we also calculate the food group production diversity (FGPD) in the households. We consider only nine food groups (i.e. cereals, pulses, tubers, vegetables, fruits, meat, fish, eggs, and milk products) for the third measure. Considering the difficulty of producing sweets, oils and fats, and spices by farmers, these groups are not considered in the indicator. Similar measures with varying specifications have been employed in recent studies (Chegere and Stage 2020; Koppmair et al. 2016; Pellegrini and Tasciotti 2014; Sibhatu and Qaim 2018a).

These three measures are used in the analyses to check for the robustness of the conclusions about the determinants of production diversity and its association with dietary quality at the household level. It also enables us to compare the magnitude and significance of the association of the three measures with dietary quality. In addition, we can evaluate the economic significance of the different diversification strategies, since each of the measures we employ has different qualities, such as capturing the evenness of production in addition to richness (i.e. SID) and representing the direct contribution to diverse diets (i.e. production diversity by food groups).

\subsection{Dietary quality measure}

Dietary diversity can be defined by simply looking at the variety of foods consumed from major food groups (KrebsSmith et al. 1987). To capture the dietary quality of the surveyed households, we calculate the household dietary diversity score (HDDS). HDDS is an indicator of economic access to food which describes the household's ability to access 
various food items (Kennedy et al. 2011). Diverse diets are associated with higher caloric availability at household level and better food access at an individual level (Hoddinott and Yohannes 2002). Considering the its association with per capita income and energy availability, Ruel (2003) finds dietary diversity practical to capture food security status. Dietary diversity is further significantly associated with nutrient adequacy which is an aspect of dietary quality for individuals (Foote et al. 2004; Krebs-Smith et al. 1987). At household level, it is associated with many nutritional indicators like protein, fat, carbohydrates and different vitamins; and individual dietary diversity is associated with higher micronutrient intake (Fongar et al. 2019). Thus, dietary diversity is a good proxy of individual's dietary quality. Moreover, considering that individual and household level dietary diversity scores are observed to be correlated in different settings (CisseEgbuonye et al. 2017; Fongar et al. 2019; Koppmair et al. 2016; Olney et al. 2009), it is safe to assume that HDDS is a good measure of a household's overall dietary quality.

Studies have used 24-h (e.g. Koppmair et al. 2016; M'Kaibi et al. 2017) and seven-day (e.g. Jones 2017b; Jones et al. 2014; Sibhatu and Qaim 2017) recall periods to capture dietary diversity. Regular fasting (i.e. not eating animal products on Wednesdays and Fridays) is practiced by some devoted Ethiopian Orthodox Christians. Considering this, seven-day recall that captures day-today variation in diets can be more relevant to capture dietary quality than the 24-h recall. Moreover, Sibhatu and Qaim (2018a) and Chegere and Stage (2020) highlighted tradeoffs associated with the two recall periods. Although, a seven-day recall is capable of capturing more of the daily variation in diets, it is also more likely to suffer from potential recall bias than the $24-\mathrm{h}$ recall. Seven-day recall can capture foods that are consumed once or twice a week and are important for nutrition. These types of food are not likely to suffer recall biases. We opt to capture day-to-day variation in diets; HDDS is calculated from seven-day consumption recall data where food items are grouped into 12 food groups: cereals; white tubers and roots; vegetables; fruits; meat; eggs; fish and other seafood; legumes, nuts and seeds; milk and milk products; oils and fats; sweets; spices, condiments and beverages. Considering that the contribution of the last three food groups to dietary quality is debatable and have been excluded in recent studies (Islam et al. 2018; Sibhatu et al. 2015), as a sensitivity test, we also run the analyses on dietary diversity based on nine food groups (HDDS9) that better reflect micronutrient adequacy (Kennedy et al. 2011).

\subsection{Other covariates}

Both production diversification and dietary diversity may be influenced by different socioeconomic and demographic factors.
On the demographic characteristics, we control for sex, age and years of formal education of the household head, along with the household size and dependency ratio in all our analyses, thereby capturing overall human capital endowment of households which, in turn, determines many livelihood outcomes.

In the first part of the analyses, the main determinants of production diversification are investigated. We review the literature by Rehima et al. (2013), Sichoongwe et al. (2014), Isnansetyo et al. (2017), Burchfield and La Poterie (2018), Mekuria and Mekonnen (2018), and Mofya-Mukuka and Hichaambwa (2018) to identify relevant covariates and include them to the estimations. We include cultivated land area, agricultural asset value, non-farm income and total livestock units owned as household wealth indicators. Moreover, proximity to input and output markets may determine the diversification decision, thus we include time spent traveling to the nearest periodic market and input dealer. Considering the importance of institutional and technological endowments for rural livelihoods, access to an extension and the main information provided in the extension visits are included in an interaction term. On the technological aspects, the effect of irrigation and the adoption of crop rotation and intercropping practices are investigated.

In the second part of the analyses, we estimate the effect of the three production diversity measures on household dietary diversity (HDDS) where wealth indicators and market access variables from the first part remain, and a dummy indicating the receipt of remittance is added. Furthermore, the average share of crop harvest sold is calculated and added to control for the market orientation of the households. These variables are added based on the study objectives and review of existing literature (Hirvonen and Hoddinott 2017; Islam et al. 2018; Koppmair et al. 2016; Pellegrini and Tasciotti 2014; Sibhatu et al. 2015; Sibhatu and Qaim 2018a).

The second objective of the study is to estimate the effect of female participation in decision-making on two outcome variables, production diversity and dietary diversity. We look into intra-household decision-making processes regarding crop production and household expenditure in production diversity and dietary diversity models, respectively. Decision regarding household expenditure is a proxy for female involvement in consumption decision. In each decision-making process, households are divided into three categories (i.e. sole, joint, none) according to the female involvement in respective decisions. Firstly, if the decision on at least one crop grown or one type of household expenditure is made by female only, a household is assigned to the "sole" category in the respective decision variables. The "joint" category includes remaining households in which decision-making on at least one crop grown or one type of household expenditure is made jointly by male and female. Finally, all remaining households falls into the category "none" which indicates that the respective decisions in the households were made by male only. 


\subsection{Estimation methods}

Considering that the production diversity measures of simple species count and food group count are count variables, we employ fixed-effects Poisson model to estimate the determinants of production diversification. For the SID measure, which is a fractional variable ranging from zero to one, we run the pooled fractional probit (PFP) to have robust estimates (Papke and Wooldridge 2008) and employ correlated random effects (CRE) by adding the time averages of all time-varying independent variables to control for unobserved heterogeneity (Mofya-Mukuka and Hichaambwa 2018).

In the second part of the analysis, we estimate the determinants of household dietary diversity. Here, the main variables of interest are production diversity and women's participation in decision-making regarding household expenditures. The results from model specification tests, such as BreuschPagan and Hausman tests (available on request), suggest that pooled specification is more appropriate for our data. Nevertheless, we need to consider that farm diversification is also a decision that households make and it is likely to be affected by same unobservable household characteristics like skills, motivation, bond between family members and tradition to care for the well-being of the family that may also influence dietary quality. The results in pooled specification can be over or under estimated. To overcome these potential biases, we take the advantage of panel data and focus on changes within household over-time while controlling for time invariant unobservable household characteristics by employing fixed-effects model and adding a year dummy that controls for any unobserved special events (Islam et al. 2018; Muriithi and Matz 2015). We report findings from both pooled and fixed-effects models. Our dependent variables, HDDS and HDDS9, are count variables and Poisson model is the most appropriate choice of estimation. When appropriate, we estimate the models with clustered standard errors ${ }^{2}$ at the village level to account for within village correlation.

\section{Results and discussion}

\subsection{Sample characteristics}

We start the analyses by firstly summarizing the households in Table 1. There has been a significant increase in average number of crop and livestock species produced from the first survey round to the second. A significant increase is also observed in the average number of food groups produced. On

\footnotetext{
$\overline{2}$ The are 29 clusters. To check for any potential over-rejection of null effect size, we employ procedure described in Cameron et al. (2008). We do so using clusterbs command in STATA 15 by Menger (2015). We run the model with 5000 bootstrap iterations. Overall, results do not change.
}

average, households are observed to produce seven species that belong to three food groups. Mean dietary diversity significantly improved in the second round, which, however, is not the case when considering only 9 food groups. Looking into intra-household decision-making, from the first to the second round, there has been a significant increase in the average share of households where males decide regarding expenditures. This share has significantly fallen for the cases where only females are the decision makers. In the decision domains for both crop production and household expenditures, households mostly fall into the joint decision-making category. Average landholding, total livestock unit, and expenditure on durables and services have increased indicating improvements in the wealth statuses of the sampled households over the years. Moreover, on average, we observe significant increases in commercialization and adoption of crop rotation or intercropping practices. All these improvements may be associated with an observed increase in mean dietary diversity. We examine this association after studying the main determinants of production diversification.

\subsection{Diversity in farm production}

Table 2 reports the results from regression analyses where we estimate the determinants of production diversification at household level. Employing three measures of production diversification as left hand-side variables (LHV), we run PFP with CRE and fixed-effects models. Results indicate that area dedicated to crop production and adoption of crop rotation or intercropping practices associate with richness and evenness of cultivated crop species (i.e. SID) and the number of different crop and livestock species produced (i.e. species count). We also observe a negative association of non-farm income with these two outcome variables. This means that the households who are more dependent on agriculture are probably more motivated to diversify their agricultural production as an ex-ante risk management strategy. Moreover, involvement of women, be it sole or jointly, in decision-making processes regarding crop grown significantly and positively associates with the number of species and food groups produced. We do not observe any significant association when concentrating on SID that captures both the evenness and richness of crop species. This could be due to women being involved in the decision-making on a small part of the total cropped area, such as on the crops grown in the kitchen gardens. This changes the number of crops and crop groups grown, but, since kitchen gardens are relatively small, their contribution to SID is diluted. Figure 1 depicts the extent of crops where the decision to grow them is made solely by women (hereafter referred to as women's crop). In $50 \%$ and $62 \%$ of the cases, women's crops are grown in less than one-fifth of the total cultivated area in 2014 and 2016, respectively. 
Table 1 Summary statistics

\begin{tabular}{|c|c|c|c|c|}
\hline Variables & Description & Year: 2014 & Year: 2016 & $\begin{array}{l}\text { Mean } \\
\text { difference }\end{array}$ \\
\hline \multicolumn{5}{|l|}{ Diversity indicators } \\
\hline SID & Simpson's Index of Diversification. & $0.54(0.20)$ & $0.56(0.21)$ & 0.01 \\
\hline Species count & $\begin{array}{l}\text { Number of different crops and livestock species produced per HH in past } \\
12 \text { months. }\end{array}$ & $7.16(2.83)$ & $7.75(3.02)$ & $0.58 * * *$ \\
\hline FGPD & $\begin{array}{l}\text { Food group production diversity. Number of different food crops and animal } \\
\text { products produced belonging to different food groups. Maximum of } 9 \\
\text { food groups considered. }\end{array}$ & $2.65(1.16)$ & $3.83(1.30)$ & $1.18 * * *$ \\
\hline HDDS & Household dietary diversity score. & $6.36(1.68)$ & $6.71(1.51)$ & $0.35 * *$ \\
\hline HDDS9 & $\begin{array}{l}\text { Household dietary diversity score based on nine food groups that better } \\
\text { reflect micronutrient adequacy. }\end{array}$ & $4.23(1.38)$ & $4.21(1.34)$ & -0.02 \\
\hline \multicolumn{5}{|l|}{ Decision-making variables } \\
\hline $\begin{array}{l}\text { Decision-making regarding } \\
\text { crop grown - None }\end{array}$ & $\begin{array}{l}=1 \text { if there was no female participation in decision-making regarding any } \\
\text { crop grown. }\end{array}$ & $0.27(0.44)$ & $0.31(0.46)$ & 0.04 \\
\hline $\begin{array}{l}\text { Decision-making regarding } \\
\text { crop grown - Joint }\end{array}$ & $=1$ if there was a joint decision-making regarding at least one crop grown. & $0.64(0.48)$ & $0.58(0.49)$ & -0.06 \\
\hline $\begin{array}{l}\text { Decision-making regarding } \\
\text { crop grown - Sole }\end{array}$ & $=1$ if female solely made a decision on at least one crop grown. & $0.09(0.29)$ & $0.12(0.32)$ & 0.03 \\
\hline $\begin{array}{l}\text { Decision-making regarding } \\
\text { household expenditure-- } \\
\text { None }\end{array}$ & $\begin{array}{l}=1 \text { if there was no female participation in decision-making regarding any } \\
\text { type of } \mathrm{HH} \text { purchases. }\end{array}$ & $0.03(0.16)$ & $0.14(0.34)$ & $0.11 * * *$ \\
\hline $\begin{array}{l}\text { Decision-making regarding } \\
\text { household expenditure - } \\
\text { Joint }\end{array}$ & $\begin{aligned}=1 & \text { if there was a joint decision-making regarding at least one any type of } \mathrm{HH} \\
& \text { purchases. }\end{aligned}$ & $0.56(0.50)$ & $0.57(0.49)$ & 0.01 \\
\hline $\begin{array}{l}\text { Decision-making regarding } \\
\text { household expenditure - } \\
\text { Sole }\end{array}$ & $=1$ if female solely made a decision on at least one type of $\mathrm{HH}$ purchases. & $0.41(0.49)$ & $0.29(0.45)$ & $-0.12 * * *$ \\
\hline \multicolumn{5}{|c|}{ Other household level socio-economic indicators } \\
\hline Household (HH) head sex & $=1$ if the $\mathrm{HH}$ head is Female. & $0.14(0.35)$ & $0.15(0.36)$ & 0.01 \\
\hline HH head age & Age of the HH head (years). & $44.20(13.59)$ & $47.26(13.03)$ & $3.06 * * *$ \\
\hline HH head edu & Years of formal schooling for the HH head (years). & $3.23(3.56)$ & $3.20(3.57)$ & -0.03 \\
\hline HH size & Number of $\mathrm{HH}$ members. & $6.46(2.19)$ & $6.54(2.26)$ & 0.09 \\
\hline Landholding & Total land area of parcels owned or rented. & $1.43(1.17)$ & $1.66(1.55)$ & $0.23 * *$ \\
\hline Cultivated land & Total cultivated land area & $1.32(1.08)$ & $1.56(1.46)$ & $0.24 * *$ \\
\hline Market distance & Travel time; minutes it takes to get to the nearest periodic market. & $52.40(45.05)$ & $47.27(39.96)$ & -5.14 \\
\hline Agricultural asset value & Value of agricultural assets owned (1000 Ethiopian Birr (ETB)). & $0.60(1.46)$ & $0.80(1.69)$ & 0.20 \\
\hline Non-farm income & Income from non-farm activities in past 12 months (1000 ETB). & $2.60(6.81)$ & $3.62(7.81)$ & 1.02 \\
\hline $\begin{array}{l}\text { Expenditure on durables } \\
\text { and services }\end{array}$ & Total expenditure on durables and services in the past 30 days (1000 ETB). & $0.13(0.01)$ & $0.22(0.02)$ & $0.09 * * *$ \\
\hline Total livestock unit & $\begin{array}{l}\text { Total livestock unit owned. Factors are: cattle }=0.7 \text {, sheep and goats }=0.1 \text {, } \\
\text { chicken }=0.01 .(\text { Harvest Choice 2011) }\end{array}$ & $3.89(4.34)$ & $4.69(4.71)$ & $0.80 * *$ \\
\hline Extension & $=1$ if $\mathrm{HH}$ received extension in past 12 months. & $0.70(0.46)$ & $0.69(0.46)$ & -0.01 \\
\hline Rotation/Intercropping & $\mathrm{HH}$ is aware of and employs crop rotation or intercropping practices or both. & $0.48(0.50)$ & $0.69(0.46)$ & $0.21 * * *$ \\
\hline Share sold & $\begin{array}{l}\text { Average share of crop harvest sold (\%) in past } 12 \text { months. Calculated for } \\
\text { each crop grown and averaged at household level. }\end{array}$ & $27.99(22.59)$ & $32.09(23.79)$ & $4.10^{* *}$ \\
\hline Remittance & $=1$ if $\mathrm{HH}$ received any remittance in past 12 months. & $0.08(0.28)$ & $0.10(0.30)$ & 0.02 \\
\hline
\end{tabular}

Standard deviations in parenthesis. Average exchange rates: in 2014,1 USD $\approx 19.7 \mathrm{ETB}$; in 2016, 1 USD $\approx 21.8$ ETB (Exchange Rates UK 2019); *** $p<0.01, * * p<0.05, * p<0.1$

\subsection{Production diversity, decision-making, and dietary quality}

Table 3 shows the estimation results of pooled and fixedeffects Poisson models where our main right-hand side
(RHS) variables of interest are production diversity measures and women's decision-making regarding purchased food. Left-hand side (LHS) variable is HDDS. We also employ HDDS9 as LHS variable and report results in Appendix Table 5. All production diversity measures are 
Table 2 Production diversification: PFP with CRE and fixed-effects model estimates

\begin{tabular}{|c|c|c|c|}
\hline \multirow[t]{2}{*}{ Variables } & \multirow{2}{*}{$\begin{array}{l}\text { PFP with } \\
\text { CRE } \\
\text { LHV: } \\
\text { SID }\end{array}$} & \multicolumn{2}{|l|}{ Fixed-effects } \\
\hline & & $\begin{array}{l}\text { LHV: } \\
\text { Species } \\
\text { count }\end{array}$ & $\begin{array}{l}\text { LHV: } \\
\text { FGPD }\end{array}$ \\
\hline $\begin{array}{l}\text { Decision-making regarding crop } \\
\text { grown - Joint }\end{array}$ & $\begin{array}{c}0.068 \\
(0.060)\end{array}$ & $\begin{array}{c}0.096^{* * * *} \\
(0.032)\end{array}$ & $\begin{array}{c}0.149 * * * \\
(0.042)\end{array}$ \\
\hline $\begin{array}{l}\text { Decision-making regarding crop } \\
\text { grown - Sole }\end{array}$ & $\begin{array}{c}0.029 \\
(0.099)\end{array}$ & $\begin{array}{l}0.135^{* *} \\
(0.061)\end{array}$ & $\begin{array}{l}0.163 * * \\
(0.071)\end{array}$ \\
\hline Input distance & $\begin{array}{l}-0.000 \\
(0.001)\end{array}$ & $\begin{array}{l}-0.000 \\
(0.000)\end{array}$ & $\begin{array}{c}0.000 \\
(0.001)\end{array}$ \\
\hline Market distance & $\begin{array}{l}-0.001 \\
(0.001)\end{array}$ & $\begin{array}{l}-0.000 \\
(0.001)\end{array}$ & $\begin{array}{l}-0.000 \\
(0.001)\end{array}$ \\
\hline $\begin{array}{l}\text { Agricultural asset value (1000 } \\
\text { ETB) }\end{array}$ & $\begin{array}{l}-0.011 \\
(0.016)\end{array}$ & $\begin{array}{c}0.004 \\
(0.011)\end{array}$ & $\begin{array}{c}0.009 \\
(0.010)\end{array}$ \\
\hline Cultivated land (ha) & $\begin{array}{l}0.064 * * \\
(0.027)\end{array}$ & $\begin{array}{c}0.046^{* * * *} \\
(0.013)\end{array}$ & $\begin{array}{c}0.020 \\
(0.018)\end{array}$ \\
\hline Total livestock unit & $\begin{array}{c}0.014 \\
(0.009)\end{array}$ & $\begin{array}{c}0.029 * * * \\
(0.006)\end{array}$ & $\begin{array}{l}0.014 * * \\
(0.007)\end{array}$ \\
\hline Non-farm income (1000 ETB) & $\begin{array}{c}-0.007 * * \\
(0.003)\end{array}$ & $\begin{array}{c}-0.005^{* *} \\
(0.002)\end{array}$ & $\begin{array}{l}-0.002 \\
(0.002)\end{array}$ \\
\hline $\begin{array}{l}\text { Expenditure on durables and } \\
\text { services (1000 ETB) }\end{array}$ & $\begin{array}{l}-0.065 \\
(0.107)\end{array}$ & $\begin{array}{l}0.100 * * \\
(0.045)\end{array}$ & $\begin{array}{l}0.118^{* *} \\
(0.050)\end{array}$ \\
\hline Rotation/Intercropping & $\begin{array}{l}0.154 * * \\
(0.060)\end{array}$ & $\begin{array}{c}0.113 * * * \\
(0.036)\end{array}$ & $\begin{array}{c}0.046 \\
(0.041)\end{array}$ \\
\hline Irrigation & $\begin{array}{c}0.035 \\
(0.145)\end{array}$ & $\begin{array}{c}0.257 * * * \\
(0.083)\end{array}$ & $\begin{array}{c}0.062 \\
(0.092)\end{array}$ \\
\hline Extension & $\begin{array}{c}0.076 \\
(0.082)\end{array}$ & $\begin{array}{l}-0.018 \\
(0.045)\end{array}$ & $\begin{array}{c}0.010 \\
(0.053)\end{array}$ \\
\hline $\begin{array}{l}\text { [Extension] x [Main information - } \\
\text { crop management] }\end{array}$ & $\begin{array}{c}0.084 \\
(0.059)\end{array}$ & $\begin{array}{c}0.048 \\
(0.034)\end{array}$ & $\begin{array}{c}0.057 \\
(0.044)\end{array}$ \\
\hline Observations & 726 & 726 & 726 \\
\hline Wald $\chi^{2}$ & $141.45^{* *} *$ & $109.61 * * *$ & $279.88 * * *$ \\
\hline
\end{tabular}

Robust standard errors in parenthesis. Estimation controls for head sex, head age, head education, HH size, dependency ratio, and year 2016 that are not reported due to space limitations. $* * * p<0.01$, ** $p<0.05$, * $p<0.1$

positively associated with HDDS in both pooled and fixed-effects specifications. In pooled specification, we observe that an increase in the number of species produced is associated with a $1.5 \%$ increase in the number of food groups consumed. Increasing the production by one food group is associated with a $3.4 \%$ increase in HDDS. In the fixed-effects specification, a unit increase in the number of species and food groups produced are associated with $1.1 \%$ and $2.1 \%$ higher HDDS, respectively. Overall, the magnitudes are very small. The magnitude of women's participation in decision-making regarding household expenditures is generally much larger than that of production diversity measures. We observe that decision-making regarding household expenditures made jointly and by women only are associated with around $9 \%$ and $13 \%$ increases in HDDS, respectively. The results are similar when restricting diet diversity to nine food groups (see Appendix Table 5). Moreover, wealth indicators significantly and positively associate with dietary quality. Overall, we observe that wealth and women's participation in decision-making are robust determinants of dietary diversity. Market distance and commercialization are significantly associated with dietary quality in pooled specification, but not when concentrating on changes within households over time.

The magnitudes of association between different production diversity measures and dietary quality are small. Furthermore, diversification interacts with other household characteristics that modify these magnitudes. For example, if we compare a household with high non-farm income who is less dependent on agriculture with a household with no or very low non-farm income, production diversification can be more significant for the latter in terms of dietary quality. The same can be hypothesized when comparing mostly market-oriented household with highly subsistence-oriented households. This conditionality of the association demands the analysis to be extended before meaningful conclusions with better credibility can be reached.

\subsection{Extended model of association between production and dietary diversity}

The association of production diversity with dietary diversity is conditional on household characteristics. For example, the benefit of diversification for households that are highly market-oriented or that specialized in the production of specific crop or livestock is questionable. Considering the importance of a household's market orientation, we extend the model by adding an interaction term of the production diversity measures with market participation, which is captured by the average share of crop product sold. Household consumption is rarely attributable to only on-farm production. Considering that households in close distances to the markets have possibilities to also diversify their diets by purchasing from markets, it is plausible to hypothesize larger magnitudes of association between production diversity and dietary diversity for households that are further away from the markets. Moreover, the level of non-farm income can define the significance of on-farm production diversity for dietary quality. Diversification can reflect more gains in dietary diversity for households with limited or no income options outside agricultural production. Thus, we further interact market distance and non-farm income, 
Fig. 1 Frequency histogram: the share of women's crop (i.e. solely decided by women) in total cropped area for households that fall into sole female decision category
Year: 2014

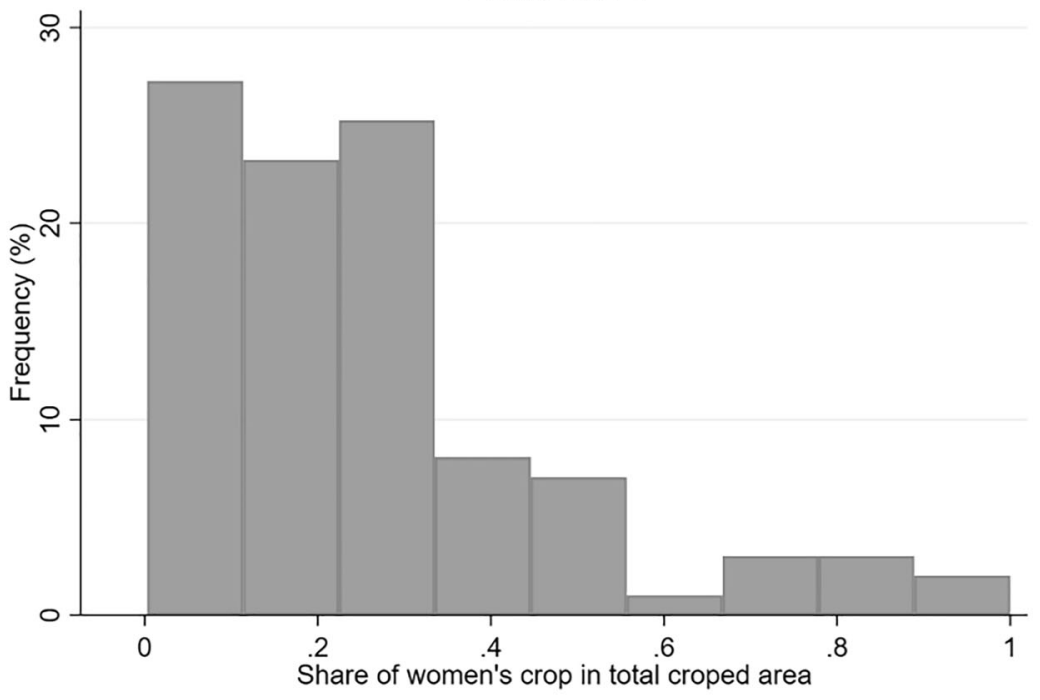

Year: 2016

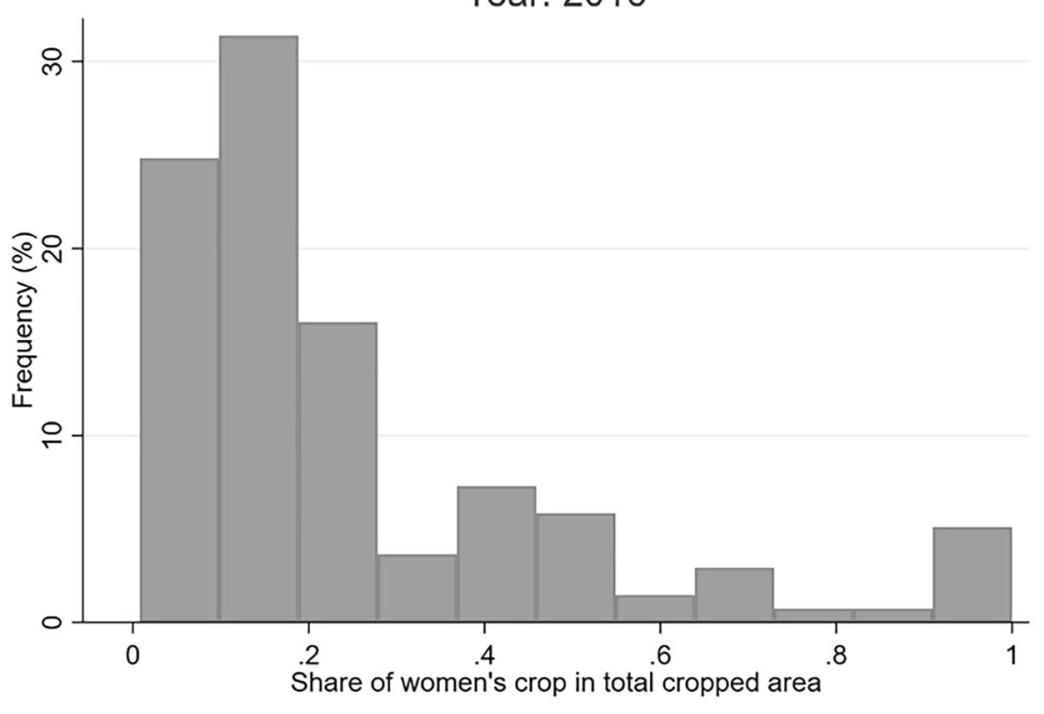

respectively, with diversity measures. Moreover, considering the foregone benefits from specialization in already highly diversified farms, we include a square of the diversity terms into the analyses. We extend our model to have a clearer understanding of the association between production and dietary diversity.

Table 4 reports the estimation results of the extended model of dietary quality. It is important to highlight that we cannot make any immediate conclusions from Table 4. Insignificant coefficient of interaction term neither means that there is no interaction nor the interaction term should be dropped. The coefficient of interaction term should neither be interpreted as marginal effect nor assumed as meaningful conditional effect. This effect can be of opposite sign, significant and insignificant depending on the actual values of interacting variables (Ai and Norton 2003; Brambor et al. 2006). Although the coefficients of interaction terms are insignificant, it is possible that the marginal effect of production diversity is significant for a range of the other terms that are interacted with production diversity measures. The opposite is also true.

We follow the recommendation of Brambor et al. (2006) and calculate the marginal effect of production diversity indicators along with respective standard errors 
Table 3 Dietary quality: pooled and fixed-effects Poisson model estimates

\begin{tabular}{|c|c|c|c|c|c|c|}
\hline \multirow[b]{2}{*}{ Variables } & \multicolumn{3}{|c|}{ Pooled models } & \multicolumn{3}{|c|}{ Fixed models } \\
\hline & $\begin{array}{l}\text { RHS: } \\
\text { SID }\end{array}$ & $\begin{array}{l}\text { RHS: } \\
\text { species } \\
\text { count }\end{array}$ & $\begin{array}{l}\text { RHS: } \\
\text { FGPD }\end{array}$ & $\begin{array}{l}\text { RHS: } \\
\text { SID }\end{array}$ & $\begin{array}{l}\text { RHS: } \\
\text { species } \\
\text { count }\end{array}$ & $\begin{array}{l}\text { RHS: } \\
\text { FGPD }\end{array}$ \\
\hline Production diversity & $\begin{array}{c}0.130 * * \\
(0.053)\end{array}$ & $\begin{array}{c}0.015 * * * \\
(0.003)\end{array}$ & $\begin{array}{c}0.034 * * * \\
(0.006)\end{array}$ & $\begin{array}{l}0.126^{*} \\
(0.075)\end{array}$ & $\begin{array}{c}0.011 * * \\
(0.005)\end{array}$ & $\begin{array}{l}0.021 * \\
(0.011)\end{array}$ \\
\hline $\begin{array}{l}\text { Decision-making regarding } \\
\text { household expenditure - } \\
\text { Joint }\end{array}$ & $\begin{array}{l}0.063 * \\
(0.037)\end{array}$ & $\begin{array}{l}0.058 * \\
(0.035)\end{array}$ & $\begin{array}{l}0.063 * \\
(0.036)\end{array}$ & $\begin{array}{c}0.098 * * \\
(0.048)\end{array}$ & $\begin{array}{c}0.103 * * \\
(0.047)\end{array}$ & $\begin{array}{c}0.104 * * \\
(0.047)\end{array}$ \\
\hline $\begin{array}{l}\text { Decision-making regarding } \\
\text { household expenditure - } \\
\text { Sole }\end{array}$ & $\begin{array}{c}0.111 * * * \\
(0.041)\end{array}$ & $\begin{array}{c}0.103 * * * \\
(0.038)\end{array}$ & $\begin{array}{c}0.111 * * * \\
(0.040)\end{array}$ & $\begin{array}{c}0.129 * * \\
(0.051)\end{array}$ & $\begin{array}{c}0.130 * * \\
(0.051)\end{array}$ & $\begin{array}{c}0.136^{* * *} \\
(0.051)\end{array}$ \\
\hline Landholding & $\begin{array}{c}0.002 \\
(0.007)\end{array}$ & $\begin{array}{l}-0.000 \\
(0.007)\end{array}$ & $\begin{array}{c}0.004 \\
(0.007)\end{array}$ & $\begin{array}{c}0.007 \\
(0.012)\end{array}$ & $\begin{array}{c}0.005 \\
(0.011)\end{array}$ & $\begin{array}{c}0.008 \\
(0.011)\end{array}$ \\
\hline Total livestock unit & $\begin{array}{c}0.011 * * * \\
(0.002)\end{array}$ & $\begin{array}{c}0.010^{* * * *} \\
(0.002)\end{array}$ & $\begin{array}{c}0.010 * * * \\
(0.002)\end{array}$ & $\begin{array}{c}0.011 * * \\
(0.005)\end{array}$ & $\begin{array}{l}0.009 * \\
(0.005)\end{array}$ & $\begin{array}{c}0.010 * * \\
(0.005)\end{array}$ \\
\hline Non-farm income (1000 ETB) & $\begin{array}{c}0.004 * * * \\
(0.001)\end{array}$ & $\begin{array}{c}0.004 * * * \\
(0.001)\end{array}$ & $\begin{array}{c}0.004 * * * \\
(0.001)\end{array}$ & $\begin{array}{l}0.003 * \\
(0.002)\end{array}$ & $\begin{array}{c}0.003 * * \\
(0.002)\end{array}$ & $\begin{array}{l}0.003 * \\
(0.002)\end{array}$ \\
\hline $\begin{array}{l}\text { Expenditure on durables and } \\
\text { services (1000 ETB) }\end{array}$ & $\begin{array}{c}0.103 * * * \\
(0.024)\end{array}$ & $\begin{array}{c}0.089 * * * \\
(0.024)\end{array}$ & $\begin{array}{c}0.082 * * * \\
(0.026)\end{array}$ & $\begin{array}{l}0.075 * * \\
(0.037)\end{array}$ & $\begin{array}{l}0.061 * \\
(0.036)\end{array}$ & $\begin{array}{l}0.060 * \\
(0.036)\end{array}$ \\
\hline Remittance & $\begin{array}{c}0.041 \\
(0.026)\end{array}$ & $\begin{array}{c}0.034 \\
(0.024)\end{array}$ & $\begin{array}{c}0.033 \\
(0.026)\end{array}$ & $\begin{array}{c}0.044 \\
(0.044)\end{array}$ & $\begin{array}{c}0.042 \\
(0.045)\end{array}$ & $\begin{array}{c}0.044 \\
(0.044)\end{array}$ \\
\hline Market distance & $\begin{array}{c}-0.001 * * \\
(0.000)\end{array}$ & $\begin{array}{c}-0.001 * * \\
(0.000)\end{array}$ & $\begin{array}{c}-0.001 * * \\
(0.000)\end{array}$ & $\begin{array}{l}-0.000 \\
(0.000)\end{array}$ & $\begin{array}{l}-0.000 \\
(0.000)\end{array}$ & $\begin{array}{l}-0.000 \\
(0.000)\end{array}$ \\
\hline Share sold & $\begin{array}{l}0.001 * * \\
(0.000)\end{array}$ & $\begin{array}{l}0.001 * * \\
(0.000)\end{array}$ & $\begin{array}{l}0.001 * \\
(0.000)\end{array}$ & $\begin{array}{c}0.001 \\
(0.001)\end{array}$ & $\begin{array}{c}0.000 \\
(0.001)\end{array}$ & $\begin{array}{c}0.001 \\
(0.001)\end{array}$ \\
\hline Observations & 726 & 726 & 726 & 726 & 726 & 726 \\
\hline Wald $\chi^{2}$ & $727.89 * *$ & $536.75^{* *}$ & $641.70^{* *}$ & $48.33 * * *$ & $53.08 * * *$ & $51.88^{* * *}$ \\
\hline
\end{tabular}

Village level clustered and robust standard errors in parenthesis for pooled and fixed-effects models, respectively. Estimation controls for head sex, head age, head education, HH size, dependency ratio and year 2016 that are not reported due to space limitations. $* * * p<0.01, * * p<0.05, * p<0.1$ on HDDS in meaningful ranges of the modifying terms. Figure 2 depicts how the marginal effect of SID on dietary diversity changes depending on the values of nonfarm income, market distance and share of harvest sold. It is also important to know how the study population falls within the reported ranges. Thus, we visualize the distribution of the households as histogram in the background. The marginal effect intervals (i.e. whiskers) that include zero implies that there is no statistical significance. The figure shows that SID is positively associated with dietary diversity when there is no or low non-farm income. The association becomes statistically insignificant above non-farm income of 10,000 ETB per year. In very close distances to the market, SID shows no association with dietary diversity. The magnitude of the association is larger when market is distant. Moreover, we find no significant association between SID and dietary diversity for highly market-oriented farmers.

A unit change in SID means full diversification, thus magnitudes of the association between production diversity and dietary quality can be interpreted more easily for the species count and food group count measures. We depict how the marginal effects of species count and FGPD on HDDS change depending on the values of nonfarm income, market distance and share of the harvest sold in Figs. 3 and 4, respectively. We find significant association between species count and dietary quality when the closest market is distant, household is mostly subsistence oriented, and there is no or very low nonfarm income. Within the $95 \%$ confidence interval (CI), a unit increase in species count associates, at highest, with consuming around 0.09 more food groups. In other words, an average farmer (i.e. in terms of other covariates than market distance) would need to grow eleven more species on top of already produced seven species to increase the dietary diversity by one unit. The literature has somewhat similar findings; Chegere and Stage (2020) find that an average household in Tanzania would need to produce nine more species to increase dietary diversity by one more food group. Moreover, meta- analysis by Sibhatu 
Table 4 Extended model of dietary quality: fixed-effects Poisson model estimates

\begin{tabular}{|c|c|c|c|}
\hline \multirow[t]{2}{*}{ Variables } & \multicolumn{3}{|c|}{ Fixed-effects models } \\
\hline & SID & Species count & FGPD \\
\hline \multirow[t]{2}{*}{ Production diversity } & -0.367 & 0.015 & $0.078 * *$ \\
\hline & $(0.250)$ & $(0.016)$ & $(0.036)$ \\
\hline \multirow[t]{2}{*}{ Production diversity square } & $0.531 * *$ & -0.000 & $-0.009 *$ \\
\hline & $(0.256)$ & $(0.001)$ & $(0.005)$ \\
\hline \multirow[t]{2}{*}{ [Production diversity] $\mathrm{x}$ [non-farm income] } & -0.007 & -0.000 & 0.000 \\
\hline & $(0.009)$ & $(0.001)$ & $(0.001)$ \\
\hline \multirow[t]{2}{*}{ [Production diversity] $\mathrm{x}$ [share sold] } & -0.002 & $-0.000 * *$ & -0.000 \\
\hline & $(0.002)$ & $(0.000)$ & $(0.000)$ \\
\hline \multirow[t]{2}{*}{ [Production diversity] x [market distance] } & $0.003 * *$ & $0.000 * *$ & $0.000 * *$ \\
\hline & $(0.001)$ & $(0.000)$ & $(0.000)$ \\
\hline \multirow[t]{2}{*}{ Market distance } & $-0.002 * *$ & $-0.002 * *$ & $-0.001 *$ \\
\hline & $(0.001)$ & $(0.001)$ & $(0.001)$ \\
\hline \multirow[t]{2}{*}{ Share sold } & 0.001 & $0.003 * *$ & 0.001 \\
\hline & $(0.001)$ & $(0.001)$ & $(0.001)$ \\
\hline \multirow[t]{2}{*}{ Non-farm income } & 0.008 & 0.007 & 0.002 \\
\hline & $(0.006)$ & $(0.006)$ & $(0.004)$ \\
\hline \multirow[t]{2}{*}{ Decision-making regarding household expenditure - Joint } & $0.096 * *$ & $0.103 * *$ & $0.106 * *$ \\
\hline & $(0.047)$ & $(0.045)$ & $(0.047)$ \\
\hline \multirow[t]{2}{*}{ Decision-making regarding household expenditure - Sole } & $0.126^{* *}$ & $0.132 * * *$ & $0.135 * * *$ \\
\hline & $(0.050)$ & $(0.049)$ & $(0.050)$ \\
\hline Observations & 726 & 726 & 726 \\
\hline Wald $\chi^{2}$ & $66.00 * * *$ & $75.73 * * *$ & $67.81 * * *$ \\
\hline
\end{tabular}

Robust standard errors in parenthesis. Estimation controls for head sex, head age, head education, HH size, dependency ratio, total livestock unit, landholding, monthly expenditure on durables and services, remittance and year 2016 that are not reported due to space limitations. $* * * p<0.01, * * p<0.05, * p<0.1$ and Qaim (2018b) also finds that in Sub-Saharan Africa, an average farmer would need to diversify the farm by nine more crop or livestock species in order to boost dietary diversity by one food group.

An increase in one food group produced is associated with better dietary diversity up to non-farm income of 14,000 ETB per year, and even then, the magnitude is very small (i.e. 0.06 at highest). Extending production by one additional food group is associated, at highest, with consuming 0.14 more food groups. We find that producing another crop or livestock or increasing production by one food group is associated with higher diet diversity for farmers that consume 50 to $70 \%$ of their production. This means that for mostly market-oriented farmers, there is no direct potential gain in dietary diversity from further diversification. The results are similar when HDDS is replaced by the HDDS9 specification (see Appendix Table 6, Figs. 5 and 6). We also interacted production diversity measures with decision-making variables to check if gendered decision-making aspects modify the magnitude of the association between production and dietary diversity. Overall, there is no significant modification to the extended model. In spite of the fact that women's sole or joint decision-making related to household expenditures is better for dietary diversity than sole male decision-making, it does not modify the association between production diversity and dietary quality. This finding is similar to the finding from Malawi by Jones et al. (2014).

\section{Conclusions and policy implications}

Nutrition-sensitive agricultural research and programs have gained much attention in recent years which is justified considering that all forms of undernutrition can be widely observed in the poorest rural smallholders whose livelihoods, to a great extent, depend on agriculture. One example of such programs and research may include activities related to on-farm diversification that is believed to contribute to the diets of rural poor. So far, research has 


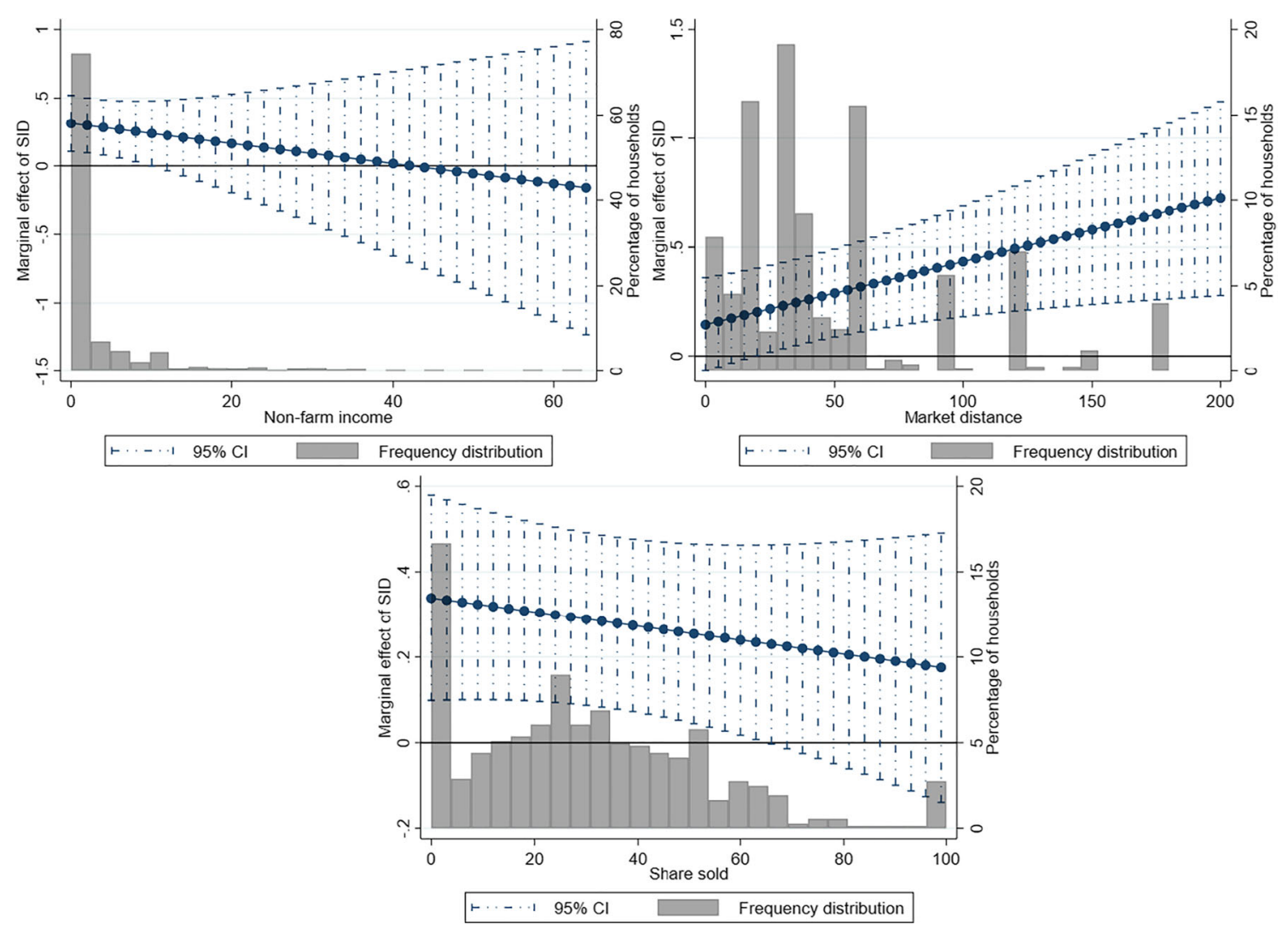

Fig. 2 The marginal effects of SID on HDDS along values of non-farm income, market distance, and share sold

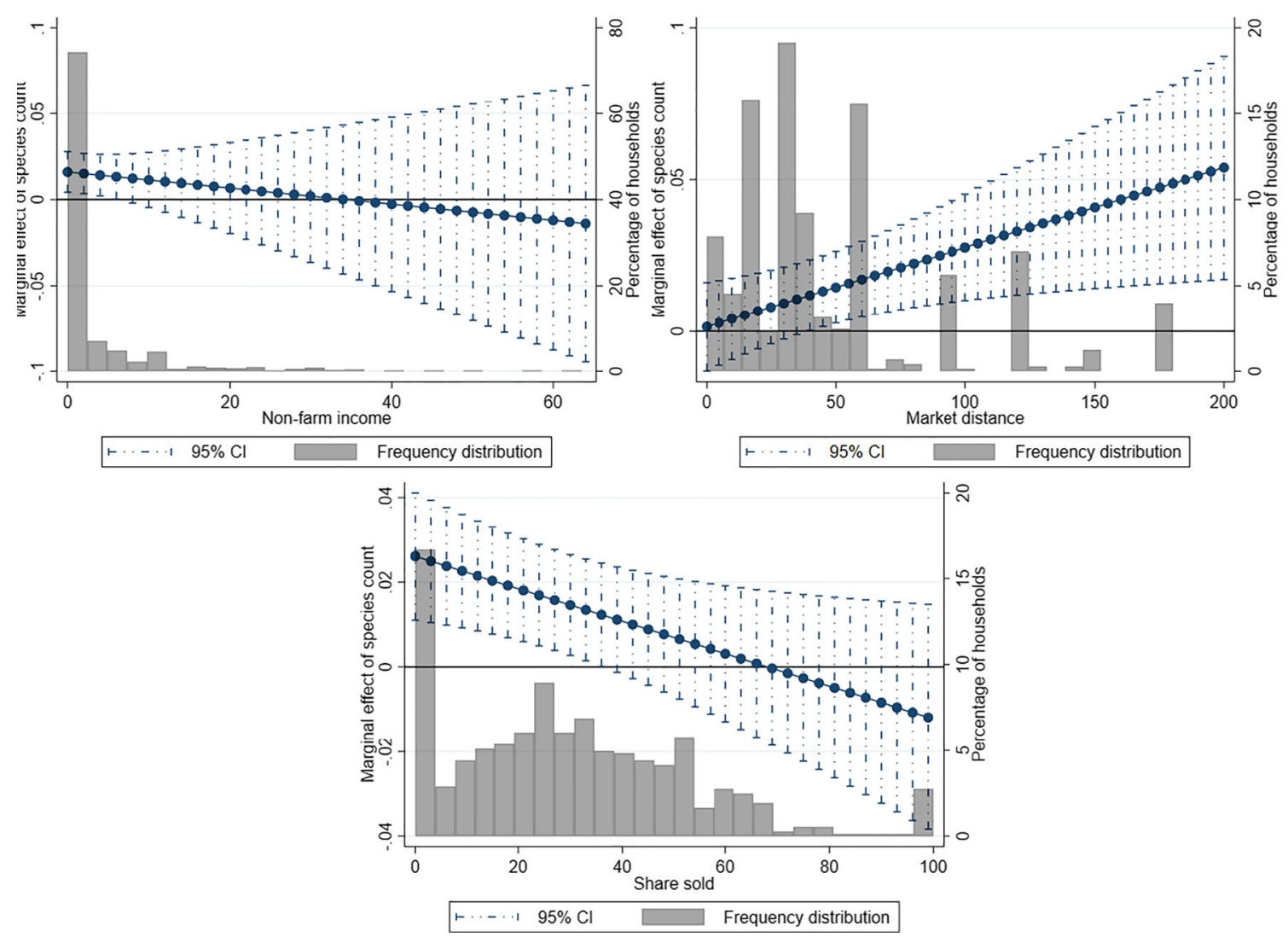

Fig. 3 The marginal effects of species count on HDDS along values of non-farm income, market distance, and share sold 


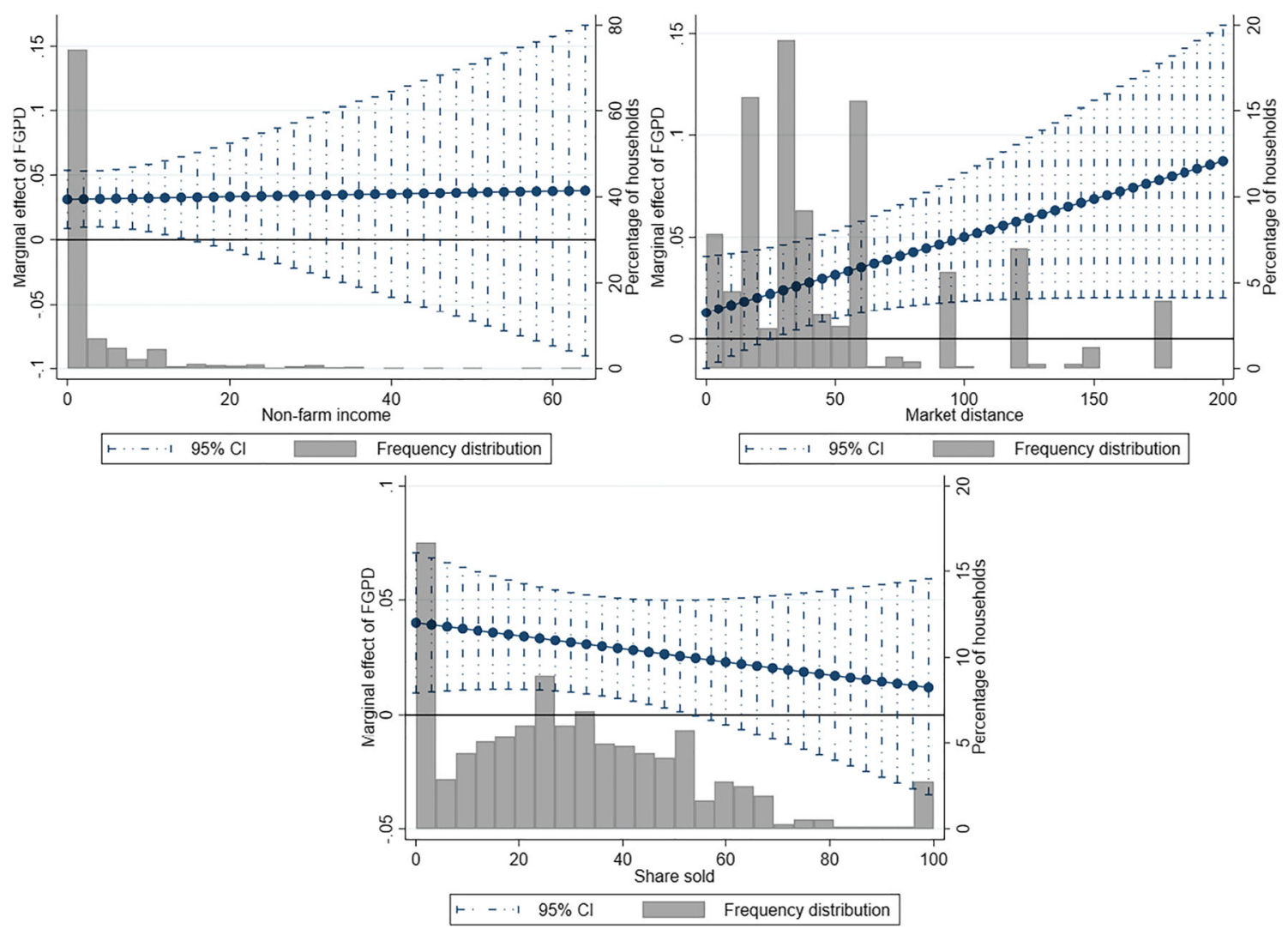

Fig. 4 The marginal effects of FGPD on HDDS along values of non-farm income, market distance, and share sold

found mixed results and significance of this association seems to be case specific.

Using panel data from Ethiopian rural households, we concentrated on production diversity at household level and looked into its association with dietary quality. Considering that this association is complex and likely to be significantly influenced by the availability of nonfarm income, distance to markets and market orientation of the households, we employed regression models with interaction terms to gain more insight into the analysis. Doing so, we also highlighted the more detailed method of interpreting the results. Furthermore, as both production and dietary diversification are decisions made by households, we examine if female participation in decision-making is linked to both livelihood outcomes, and if it can modify the magnitude of the association between production and dietary diversity.

We added year dummies in household fixed-effect regression to be able to capture the effect of any special event that might have occurred from first to the second round of the survey and would affect all households equally. Nevertheless, the analyses are limited in controlling for time-variant unobservable heterogeneity that could bias the estimations. Thus, the results are cautiously interpreted as associations.
We found that the size of the cultivated area and adoption of crop rotation or intercropping practices are linked to household level production diversity. While non-farm income was negatively associated with species count and SID that captures both the evenness and richness of crop species, female participation in decision-making variables regarding the crops produced were associated with a higher species counts and food groups produced. In addition, female participation in decisionmaking was also associated with better dietary quality. On the relationship between production diversity and dietary quality, we found that diversification can be a strategy to improve diet of rural poor who is highly and directly dependent on agricultural income, who lives far from the markets, and is mostly subsistence oriented. Yet, even in these cases the viability of achieving better dietary quality through production diversification is highly questionable, as the low magnitudes of the association mean that unrealistic changes in production diversification would be required. Moreover, in respective domains, households with women's participation in decisionmaking are associated with higher production and dietary diversity than those with sole male decision-making. However, it does not modify the association between production and dietary diversity.

We highlighted in this article an important covariate, which is gendered aspects of intra-household decision-making, for 
production diversity and dietary quality. We also highlighted the in-depth interpretation of the results when using interaction terms. Researchers should employ this in-depth approach to better assist practitioners. Furthermore, although we observe positive association between production diversity and dietary quality, this association is highly case specific. Development programs aiming to contribute to food security could adopt production diversification strategy only in rural areas with very limited market access and a lack of non-farm income possibilities; but even then, its viability is questionable. We find strong association between dietary diversity and female decision-making power and wealth indicators. Therefore, gender-inclusive social and economic development policies together with infrastructural and market development projects that contribute to household wealth and women's empowerment are recommended, as they are more promising than on-farm diversification in increasing the dietary quality.
Future literature could contribute to our knowledge base by concentrating more on district level production diversity that is likely to determine the market diversity and affordability at district level. Moreover, association between diversity in the district markets and district level food security should be rigorously investigated.

Acknowledgments The financial support of the Deutsche Forschungsgemeinschaft (DFG) [ZE 502/1-1, AOBJ 602066] is kindly acknowledged.

Funding Information Open Access funding provided by Projekt DEAL.

\section{Compliance with ethical standards}

Conflict of interest The authors declared that they have no conflict of interest.

\section{Appendix}

Table 5 Dietary quality (HDDS9): pooled and fixed-effects Poisson model estimates

\begin{tabular}{|c|c|c|c|c|c|c|}
\hline \multirow[b]{2}{*}{ Variables } & \multicolumn{3}{|c|}{ Pooled model } & \multicolumn{3}{|c|}{ Fixed effects model } \\
\hline & SID & Species count & FGDS & SID & Species count & FGPD \\
\hline \multirow[t]{2}{*}{ Production diversity } & $0.139 * * *$ & $0.020 * * *$ & $0.051 * * *$ & 0.126 & $0.015^{* *}$ & $0.033 * *$ \\
\hline & $(0.054)$ & $(0.004)$ & $(0.009)$ & $(0.099)$ & $(0.007)$ & $(0.014)$ \\
\hline \multirow[t]{2}{*}{ Decision-making regarding household expenditure - Joint } & $0.107 * *$ & $0.099 * *$ & $0.105^{* *}$ & $0.109 *$ & $0.111^{*}$ & $0.112 *$ \\
\hline & $(0.049)$ & $(0.047)$ & $(0.049)$ & $(0.066)$ & $(0.064)$ & $(0.065)$ \\
\hline \multirow[t]{2}{*}{ Decision-making regarding household expenditure - Sole } & $0.153 * * *$ & $0.141 * * *$ & $0.151 * * *$ & $0.122 *$ & $0.118^{*}$ & $0.126^{*}$ \\
\hline & $(0.053)$ & $(0.051)$ & $(0.052)$ & $(0.070)$ & $(0.069)$ & $(0.069)$ \\
\hline \multirow[t]{2}{*}{ Landholding } & -0.005 & -0.008 & -0.002 & 0.012 & 0.009 & 0.013 \\
\hline & $(0.008)$ & $(0.008)$ & $(0.009)$ & $(0.018)$ & $(0.017)$ & $(0.017)$ \\
\hline \multirow[t]{2}{*}{ Total livestock unit } & $0.014 * * *$ & $0.012 * * *$ & $0.013 * * *$ & $0.013 *$ & 0.011 & 0.012 \\
\hline & $(0.002)$ & $(0.002)$ & $(0.002)$ & $(0.008)$ & $(0.007)$ & $(0.007)$ \\
\hline \multirow[t]{2}{*}{ Non-farm income (1000 ETB) } & $0.004 * * *$ & $0.005^{* * *}$ & $0.004 * * *$ & $0.004 *$ & $0.004 *$ & $0.004 *$ \\
\hline & $(0.002)$ & $(0.002)$ & $(0.002)$ & $(0.002)$ & $(0.002)$ & $(0.002)$ \\
\hline \multirow[t]{2}{*}{ Expenditure on durables and services (1000 ETB) } & $0.131 * * *$ & $0.114 * * *$ & $0.101 * * *$ & $0.097 * *$ & $0.079 *$ & $0.076^{*}$ \\
\hline & $(0.032)$ & $(0.034)$ & $(0.036)$ & $(0.045)$ & $(0.045)$ & $(0.045)$ \\
\hline \multirow[t]{2}{*}{ Remittance } & 0.040 & 0.031 & 0.027 & 0.057 & 0.054 & 0.058 \\
\hline & $(0.033)$ & $(0.030)$ & $(0.032)$ & $(0.059)$ & $(0.060)$ & $(0.058)$ \\
\hline \multirow[t]{2}{*}{ Market distance } & -0.000 & -0.000 & $-0.001 *$ & -0.000 & -0.000 & -0.000 \\
\hline & $(0.000)$ & $(0.000)$ & $(0.000)$ & $(0.000)$ & $(0.000)$ & $(0.000)$ \\
\hline \multirow[t]{2}{*}{ Share sold } & $0.001 *$ & 0.001 & 0.001 & 0.001 & 0.000 & 0.000 \\
\hline & $(0.001)$ & $(0.001)$ & $(0.001)$ & $(0.001)$ & $(0.001)$ & $(0.001)$ \\
\hline Observations & 726 & 726 & 726 & 726 & 726 & 726 \\
\hline Wald $\chi^{2}$ & $432.38 * * *$ & $414.23 * * *$ & $432.84 * * *$ & $30.08^{* *}$ & $37.23 * * *$ & $38.16^{* * *}$ \\
\hline
\end{tabular}

Village level clustered and robust standard errors in parenthesis for pooled and fixed-effects models, respectively. Estimation controls for head sex, head age, head education, HH size, dependency ratio, and year 2016 that are not reported due to space limitations. $* * * p<0.01, * * p<0.05, * p<0.1$ 
Table 6 Extended model of dietary quality (HDDS9): fixedeffects Poisson model estimates

\begin{tabular}{|c|c|c|c|}
\hline \multirow[t]{2}{*}{ Variables } & \multicolumn{3}{|c|}{ Fixed-effects model } \\
\hline & SID & Species count & FGPD \\
\hline Production diversity & $\begin{array}{l}-0.573 * \\
(0.315)\end{array}$ & $\begin{array}{l}0.017 \\
(0.020)\end{array}$ & $\begin{array}{l}0.109 * * \\
(0.047)\end{array}$ \\
\hline Production diversity square & $\begin{array}{l}0.803 \text { ** } \\
(0.342)\end{array}$ & $\begin{array}{l}0.000 \\
(0.001)\end{array}$ & $\begin{array}{l}-0.012 * \\
(0.006)\end{array}$ \\
\hline [Production diversity] x [non-farm income] & $\begin{array}{l}-0.010 \\
(0.012)\end{array}$ & $\begin{array}{l}-0.001 \\
(0.001)\end{array}$ & $\begin{array}{l}0.001 \\
(0.001)\end{array}$ \\
\hline [Production diversity] $\mathrm{x}$ [share sold] & $\begin{array}{l}-0.002 \\
(0.003)\end{array}$ & $\begin{array}{l}-0.000 * \\
(0.000)\end{array}$ & $\begin{array}{l}-0.000 \\
(0.000)\end{array}$ \\
\hline [Production diversity] $\mathrm{x}$ [market distance] & $\begin{array}{l}0.003^{*} \\
(0.002)\end{array}$ & $\begin{array}{l}0.000 * * \\
(0.000)\end{array}$ & $\begin{array}{l}0.000 * \\
(0.000)\end{array}$ \\
\hline Market distance & $\begin{array}{l}-0.002 * \\
(0.001)\end{array}$ & $\begin{array}{l}-0.002 * * \\
(0.001)\end{array}$ & $\begin{array}{l}-0.001 \\
(0.001)\end{array}$ \\
\hline Share sold & $\begin{array}{l}0.001 \\
(0.001)\end{array}$ & $\begin{array}{l}0.003 \\
(0.002)\end{array}$ & $\begin{array}{l}0.002 \\
(0.002)\end{array}$ \\
\hline Non-farm income & $\begin{array}{l}0.010 \\
(0.008)\end{array}$ & $\begin{array}{l}0.012 \\
(0.008)\end{array}$ & $\begin{array}{l}0.001 \\
(0.005)\end{array}$ \\
\hline Decision-making regarding household expenditure - Joint & $\begin{array}{l}0.107 * \\
(0.065)\end{array}$ & $\begin{array}{l}0.110^{*} \\
(0.063)\end{array}$ & $\begin{array}{l}0.111 * \\
(0.064)\end{array}$ \\
\hline Decision-making regarding household expenditure - Sole & $\begin{array}{l}0.118^{*} \\
(0.069)\end{array}$ & $\begin{array}{l}0.120 * \\
(0.067)\end{array}$ & $\begin{array}{l}0.122 * \\
(0.068)\end{array}$ \\
\hline Observations & 726 & 726 & 726 \\
\hline Wald $\chi^{2}$ & $41.04 * *$ & $55.65 * * *$ & $52.43 * * *$ \\
\hline
\end{tabular}

Robust standard errors in parenthesis. Estimation controls for head sex, head age, head education, HH size, dependency ratio, total livestock unit, landholding, expenditure on durables and services, remittance, and year 2016 that are not reported due to space limitations. $* * * p<0.01$, ** $p<0.05, * p<0.1$

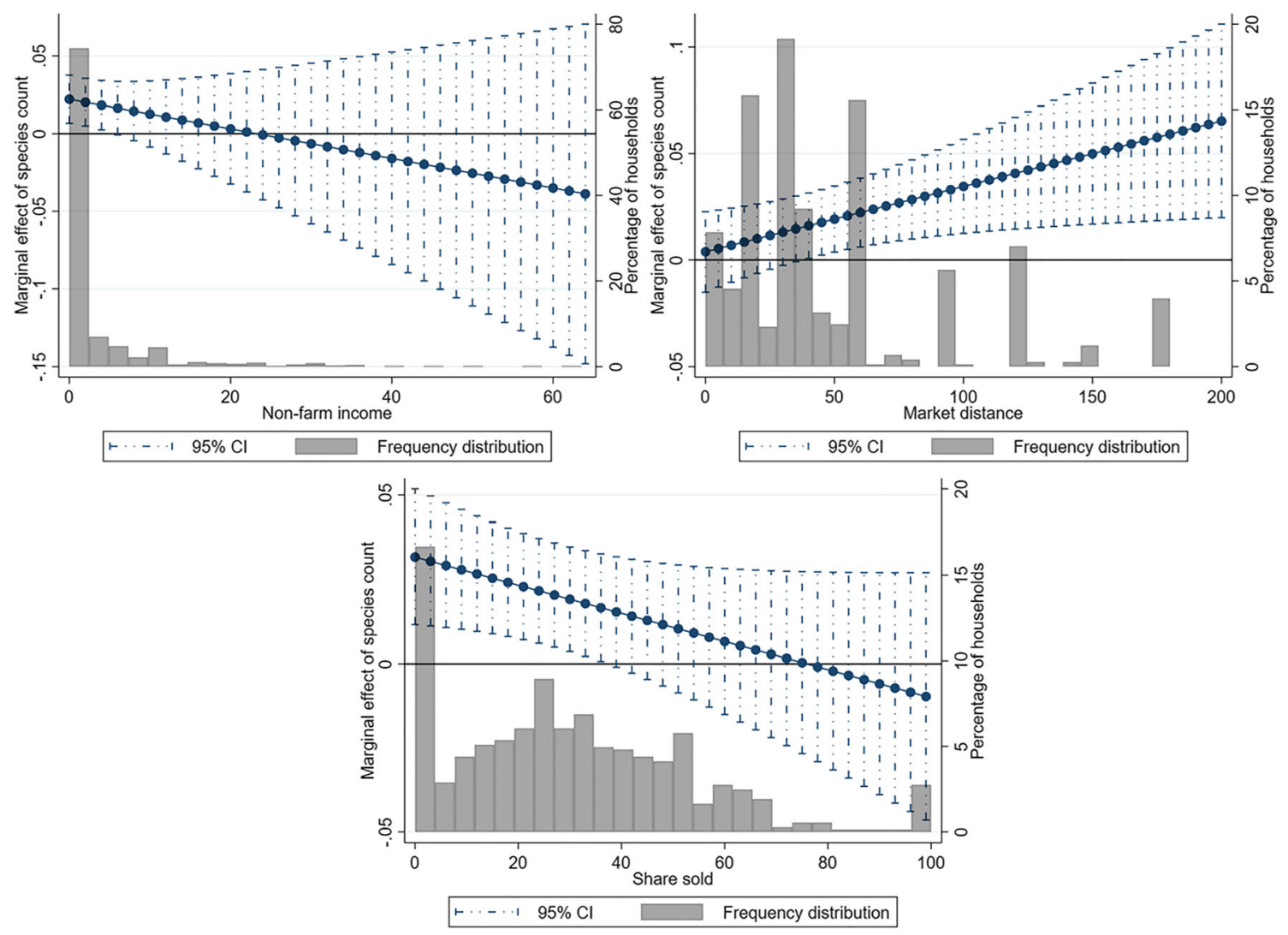

Fig. 5 The marginal effects of species count on HDDS9 along values of non-farm income, market distance, and share sold 


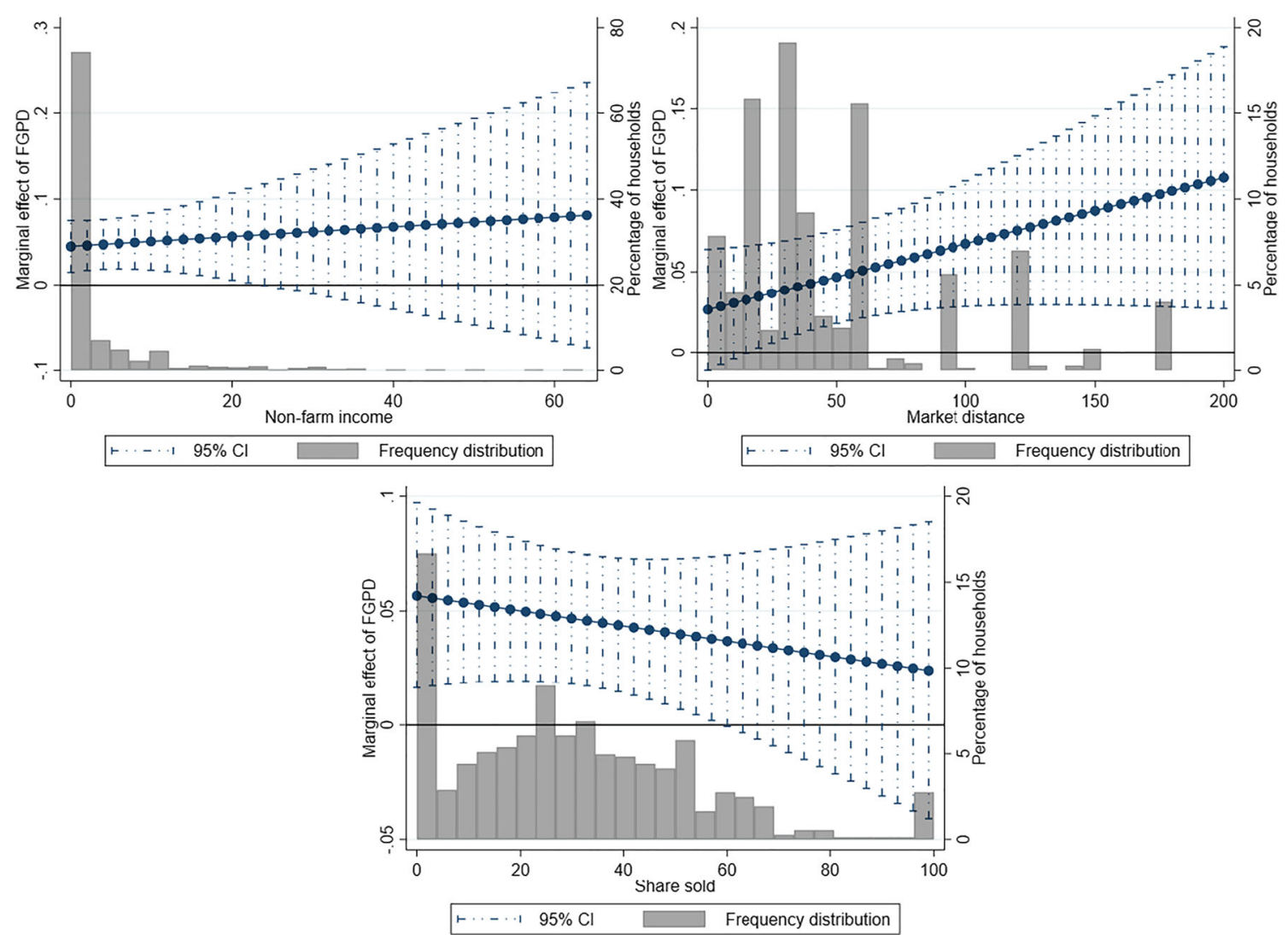

Fig. 6 The marginal effects of FGPD on HDDS9 along values of non-farm income, market distance, and share sold

Open Access This article is licensed under a Creative Commons Attribution 4.0 International License, which permits use, sharing, adaptation, distribution and reproduction in any medium or format, as long as you give appropriate credit to the original author(s) and the source, provide a link to the Creative Commons licence, and indicate if changes were made. The images or other third party material in this article are included in the article's Creative Commons licence, unless indicated otherwise in a credit line to the material. If material is not included in the article's Creative Commons licence and your intended use is not permitted by statutory regulation or exceeds the permitted use, you will need to obtain permission directly from the copyright holder. To view a copy of this licence, visit http://creativecommons.org/licenses/by/4.0/.

\section{References}

Ahmed, A., Hill, R., Smith, L., Wiesmann, D., Frankenberger, T., Gulati, K., Quabili, W., \& Yohannes, Y. (2007). The world's most deprived: Characteristics and causes of extreme poverty and hunger. International Food Policy Research Institute (IFPRI) (43). Available online at https://EconPapers.repec.org/RePEc:fpr:2020dp:43

Ai, C., \& Norton, E. C. (2003). Interaction terms in logit and probit models. Economics Letters, 80, 123-129. https://doi.org/10.1016/ S0165-1765(03)00032-6.

AU/African Union. (2015). African regional nutrition strategy 20152025. Addis Ababa: African Union.

Barrett, C. B. (2010). Food systems and the escape from poverty and illhealth traps in sub-Saharan Africa. In P. Pinstrup-Andersen (Ed.), The African food system and its interaction with human health and nutrition (pp. 242-260). Ithaca: Cornell University Press in cooperation with the United Nations University.

Brambor, T., Clark, W. R., \& Golder, M. (2006). Understanding interaction models: improving empirical analyses. Political Analysis, 14, 63-82. https://doi.org/10.1093/pan/mpi014 .

Burchfield, E. K., \& La Poterie, A. T. (2018). Determinants of crop diversification in rice-dominated Sri Lankan agricultural systems. Journal of Rural Studies, 61, 206-215. https://doi.org/10.1016/j. jrurstud.2018.05.010 .

Cameron, A. C., Gelbach, J. B., \& Miller, D. L. (2008). Bootstrap-based improvements for inference with clustered errors. The Review of Economics and Statistics, 90(3), 414-427.

Carter, N. A., Humphries, S., Grace, D., Ouma, E. A., \& Dewey, C. E. (2017). Men and women farmers' perceptions of adopting improved diets for pigs in Uganda: decision-making, income allocation, and intrahousehold strategies that mitigate relative disadvantage. Agriculture \& Food Security, 6, 705. https://doi.org/10.1186/s40066-017-0095-7 .

Chegere, M. J., \& Stage, J. (2020). Agricultural production diversity, dietary diversity and nutritional status: panel data evidence from Tanzania. World Development, 129, 104856. https://doi.org/10. 1016/j.worlddev.2019.104856 .

Cisse-Egbuonye, N., Ishdorj, A., McKyer, E. L. J., \& Mkuu, R. (2017). Examining nutritional adequacy and dietary diversity among women in Niger. Maternal and Child Health Journal, 21, 1408-1416. https://doi.org/10.1007/s10995-016-2248-x .

Di Falco, S., \& Chavas, J.-P. (2009). On crop biodiversity, risk exposure, and food security in the highlands of Ethiopia. American Journal of Agricultural Economics, 91, 599-611. https://doi.org/10.1111/j. 1467-8276.2009.01265.x.

Dixon, J., Gulliver, A., \& Gibbon, D. (2001). Farming systems and poverty: Improving farmers' livelihoods in a changing world. Rome, Italy \& Washington, DC, USA: FAO \& World Bank. 
Ecker, O. (2018). Agricultural transformation and food and nutrition security in Ghana: does farm production diversity (still) matter for household dietary diversity? Food Policy, 79, 271-282. https://doi. org/10.1016/j.foodpol.2018.08.002 .

Exchange Rates UK (2019) US Dollar to Ethiopian Birr Spot Exchange Rates for 2016. https://www.exchangerates.org.uk/USD-ETB-spotexchange-rates-history-2016.html. Accessed 13 Aug 2019.

FAO, IFAD, UNICEF, WFP and WHO. (2019). The state of food security and nutrition in the world: Safeguarding against economic slowdowns and downturns. Rome: FAO.

Fisher, M., \& Carr, E. R. (2015). The influence of gendered roles and responsibilities on the adoption of technologies that mitigate drought risk: the case of drought-tolerant maize seed in eastern Uganda. Global Environmental Change, 35, 82-92. https://doi.org/10.1016/ j.gloenvcha.2015.08.009 .

Fongar, A., Gödecke, T., Aseta, A., \& Qaim, M. (2019). How well do different dietary and nutrition assessment tools match? Insights from rural Kenya. Public Health Nutrition, 22, 391-403. https://doi.org/ $10.1017 / \mathrm{S} 1368980018002756$.

Foote, J. A., Murphy, S. P., Wilkens, L. R., Basiotis, P. P., \& Carlson, A. (2004). Dietary variety increases the probability of nutrient adequacy among adults. The Journal of Nutrition, 134, 1779-1785. https:// doi.org/10.1093/jn/134.7.1779 .

Galiè, A., Teufel, N., Girard, A. W., Baltenweck, I., Dominguez-Salas, P., Price, M. J., Jones, R., Lukuyu, B., Korir, L., Raskind, I., Smith, K., \& Yount, K. M. (2019). Women's empowerment, food security and nutrition of pastoral communities in Tanzania. Global Food Security, 23, 125-134. https://doi.org/10.1016/j.gfs.2019.04.005 .

Garikipati, S. (2008). The impact of lending to women on household vulnerability and women's empowerment: evidence from India. World Development, 36, 2620-2642. https://doi.org/10.1016/j. worlddev.2007.11.008 .

Harvest Choice (2011). Total livestock population (TLU) (2005). International Food Policy Research Institute, Washington, DC., and University of Minnesota, St. Paul, MN.

Hirvonen, K., \& Hoddinott, J. (2017). Agricultural production and children's diets: evidence from rural Ethiopia. Agricultural Economics, 48, 469-480. https://doi.org/10.1111/agec.12348 .

Hoddinott, J., \& Yohannes, Y. (2002). Dietary Diversity as a Food Security Indicator:94.

Islam, A. H. M. S., von Braun, J., Thorne-Lyman, A. L., \& Ahmed, A. U. (2018). Farm diversification and food and nutrition security in Bangladesh: empirical evidence from nationally representative household panel data. Food Security, 10, 701-720. https://doi.org/ 10.1007/s12571-018-0806-3

Isnansetyo, A., Nuringtyas, T. R., Qanti, S. R., Syamsiyah, N., Sadeli, A. H., \& Natawidjaja, R. S. (Eds.). (2017). Determinants of crop diversification by farmers in Java: Proceeding of the $1^{\text {st }}$ international conference on tropical agriculture. Springer International Publishing.

Jones, A. D. (2017a). Critical review of the emerging research evidence on agricultural biodiversity, diet diversity, and nutritional status in low- and middle-income countries. Nutrition Reviews, 75, 769-782. https://doi.org/10.1093/nutrit/nux040 .

Jones, A. D. (2017b). On-farm crop species richness is associated with household diet diversity and quality in subsistence- and marketoriented farming households in Malawi. The Journal of Nutrition, 147(1), 86-96. https://doi.org/10.3945/jn.116.235879 .

Jones, A. D., Shrinivas, A., \& Bezner-Kerr, R. (2014). Farm production diversity is associated with greater household dietary diversity in Malawi: findings from nationally representative data. Food Policy, 46, 1-12. https://doi.org/10.1016/j.foodpol.2014.02.001

Just, R. E., \& Candler, W. (1985). Production functions and rationality of mixed cropping. European Review of Agricultural Economics, 12, 207-231.
Kennedy, G., Ballard, T., \& Dop, M. C. (2011). Guidelines for measuring household and individual dietary diversity. Food and Agriculture Organization of the United Nations.

Koppmair, S., Kassie, M., \& Qaim, M. (2016). Farm production, market access and dietary diversity in Malawi. Public Health Nutrition, 20, 325-335. https://doi.org/10.1017/S1368980016002135 .

Krebs-Smith, S. M., Smiciklas-Wright, H., Guthrie, H. A., \& KrebsSmith, J. (1987). The effects of variety in food choices on dietary quality. Journal of the American Dietetic Association, 87, 897-903.

Larson, J. B., Castellanos, P., \& Jensen, L. (2019). Gender, household food security, and dietary diversity in western Honduras. Global Food Security, 20, 170-179. https://doi.org/10.1016/j.gfs.2019.01. 005 .

Linderhof, V., Powell, J., Vignes, R., \& Ruben, R. (2016). The influence of household farming systems on dietary diversity and caloric intake: the case of Uganda (African Association of Agricultural Economists (AAAE), 246444).

Malapit, H. J. L., Sraboni, E., Quisumbing, A. R., \& Ahmed, A. U. (2019). Intrahousehold empowerment gaps in agriculture and children's well-being in Bangladesh. Development Policy Review, 167, 1188-1203. https://doi.org/10.1111/dpr.12374 .

Mekuria, W., \& Mekonnen, K. (2018). Determinants of crop-livestock diversification in the mixed farming systems: evidence from central highlands of Ethiopia. Agriculture \& Food Security, 7, 1. https://doi. org/10.1186/s40066-018-0212-2 .

Menger, A. (2015). CLUSTERBS: Stata module to perform a pairs symmetric cluster bootstrap-t procedure. Statistical Software Components S457988, Boston College Department of Economics, revised 25 Jul 2015.

M'Kaibi, F. K., Steyn, N. P., Ochola, S. A., \& Du Plessis, L. (2017). The relationship between agricultural biodiversity, dietary diversity, household food security, and stunting of children in rural Kenya. Food Science \& Nutrition, 5(2), 243-254. https://doi.org/10.1002/ fsn3.387.

Mofya-Mukuka, R., \& Hichaambwa, M. (2018). Livelihood effects of crop diversification: a panel data analysis of rural farm households in Zambia. Food Security, 10, 1449-1462. https://doi.org/10.1007/ s12571-018-0872-6

Muriithi, B. W., \& Matz, J. A. (2015). Welfare effects of vegetable commercialization: Evidence from smallholder producers in Kenya. Food Policy, 50, 80-91. https://doi.org/10.1016/j.foodpol.2014.11. 001 .

Ndiritu, S. W., Kassie, M., \& Shiferaw, B. (2014). Are there systematic gender differences in the adoption of sustainable agricultural intensification practices? Evidence from Kenya. Food Policy, 49(Part 1), 117-127. https://doi.org/10.1016/j.foodpol.2014.06.010 .

Olney, D. K., Talukder, A., Iannotti, L. L., Ruel, M. T., \& Quinn, V. (2009). Assessing impact and impact pathways of a homestead food production program on household and child nutrition in Cambodia. Food and Nutrition Bulletin, 30, 355-369. https://doi.org/10.1177/ 156482650903000407

Papke, L. E., \& Wooldridge, J. M. (2008). Panel data methods for fractional response variables with an application to test pass rates. Journal of Econometrics, 145, 121-133. https://doi.org/10.1016/j. jeconom.2008.05.009

Pellegrini, L., \& Tasciotti, L. (2014). Crop diversification, dietary diversity and agricultural income: empirical evidence from eight developing countries. Canadian Journal of Development Studies / Revue canadienne d'études du développement, 35, 211-227. https://doi. org/10.1080/02255189.2014.898580 .

Rehima, M., Belay, K., Dawit, A., \& Rashid, S. (2013). Factors affecting farmers' crops diversification: evidence from SNNPR, Ethiopia. International Journal of Agricultural Sciences, 3, 558-565.

Ruel, M. T. (2003). Operationalizing dietary diversity: a review of measurement issues and research priorities. The Journal of Nutrition, 133, 3911S-3926S. https://doi.org/10.1093/jn/133.11.3911S . 
Ruel, M. T., Quisumbing, A. R., \& Balagamwala, M. (2018). Nutritionsensitive agriculture: What have we learned so far? Global Food Security, 17, 128-153. https://doi.org/10.1016/j.gfs.2018.01.002.

Sariyev, O., Loos, T.K., \& Zeller, M. (2020). Women's participation in decision-making and its implications for human capital investment. European Review of Agricultural Economics, article jbaa008. Advance online publication. https://doi.org/10.1093/erae/jbaa008

Sawyer, B., \& Minot, N. (2013). Agricultural production in Ethiopia: Key results from the 2012 ATA baseline survey. Prepared for the Ethiopian Agricultural Transformation Agency under the project "Research in Ethiopia's Agricultural Policy" funded by the Bill and Melinda Gates Foundation. Washington, DC. http://www. ifpri.org/sites/default/files/publications/reappn3.pdf.

Sibhatu, K. T., \& Qaim, M. (2017). Rural food security, subsistence agriculture, and seasonality. PLoS One, 12(10), e0186406. https:// doi.org/10.1371/journal.pone.0186406 .

Sibhatu, K. T., \& Qaim, M. (2018a). Farm production diversity and dietary quality: linkages and measurement issues. Food Security, 10, 47-59. https://doi.org/10.1007/s12571-017-0762-3 .

Sibhatu, K. T., \& Qaim, M. (2018b). Review: meta-analysis of the association between production diversity, diets, and nutrition in smallholder farm households. Food Policy, 77, 1-18. https://doi.org/10. 1016/j.foodpol.2018.04.013

Sibhatu, K. T., Krishna, V. V., \& Qaim, M. (2015). Production diversity and dietary diversity in smallholder farm households. Proceedings of the National Academy of Sciences of the United States of America, 112, 10657-10662. https://doi.org/10.1073/pnas. 1510982112

Sichoongwe, K., Mapemba, L., Tembo, G., \& Ng'ong'ola, D. (2014). The determinants and extent of crop diversification among smallholder farmers: a case study of Southern Province Zambia. Journal of Agricultural Science, 6(11). https://doi.org/10.5539/jas. v6n11p150 .

Sraboni, E., Malapit, H. J., Quisumbing, A. R., \& Ahmed, A. U. (2014). Women's empowerment in agriculture: what role for food security in Bangladesh? World Development, 61, 11-52. https://doi.org/10. 1016/j.worlddev.2014.03.025

United Nations Development Programme (2019). Goal 2: Zero hunger. https://www.undp.org/content/undp/en/home/sustainabledevelopment-goals/goal-2-zero-hunger.html. Accessed 2 May 2019.

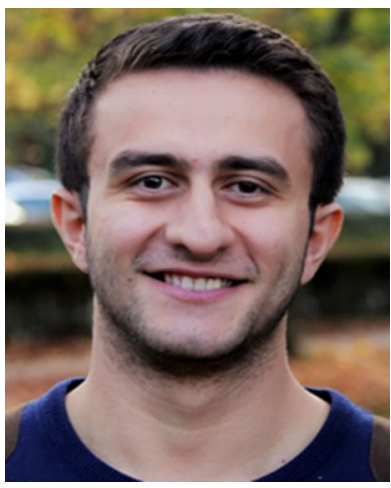

Orkhan Sariyev is a research associate at the Institute of Agricultural Sciences in the Tropics (Hans-RuthenbergInstitute), University of Hohenheim, Germany. His research mainly focuses on linkages between empowerment and livelihood in smallholder farming households of Africa and South Asia. His interests are women's empowerment, intra-household bargaining, food security, and rural livelihood development economics. He holds a bachelor's degree from the Azerbaijan State Agricultural University and a master's degree in Agricultural Economics from the University of Hohenheim. $\mathrm{He}$ is currently pursuing his $\mathrm{PhD}$ in Agricultural Economics at the University of Hohenheim.

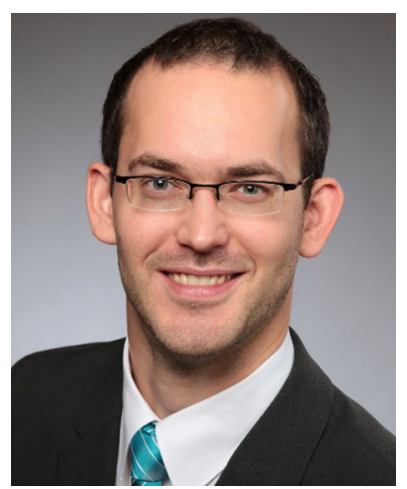

Tim K. Loos is an advisor at the Deutsche Gesellschaft für Internationale Zusammenarbeit (GIZ) GmbH, Germany. His current work focuses on developing strategies for rural farmers to achieve a living income, thereby ensuring food and nutrition security, overcoming poverty and reaching a decent standard of living. Prior to this, he was a researcher at the Food Security Center and the Institute of Agricultural Sciences in the Tropics (Hans-RuthenbergInstitute), University of Hohenheim, Germany. He holds a bachelor's degree in Agricultural Sciences, a master's degree in Natural Resource Management, and a $\mathrm{PhD}$ in Agricultural Economics from the University of Hohenheim. With diverse experience in South America and SubSaharan Africa, his research focus includes the assessment of biomassbased value chains/webs in the African bio-economy and analyses of drivers and effects of agricultural technology adoption, gender roles and women's empowerment, rural development, and food and nutrition security.

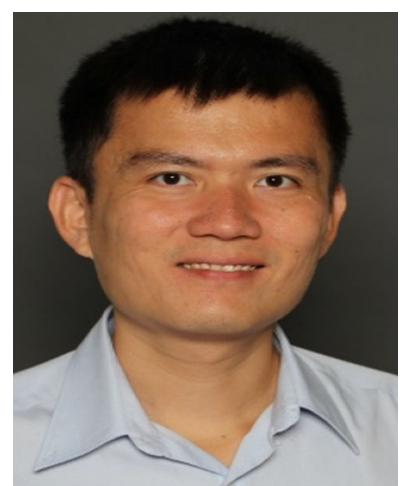

Ling Yee Khor is a research fellow at the University of Hohenheim in Germany. His current research focuses on the socioeconomic impact of biofortified beans in Guatemala with HarvestPlus and of improved tilapia strain in Myanmar with WorldFish. Before this, he worked as a $\mathrm{PhD}$ researcher in a Sino-German project on sustainable resource use in the North China Plain. His fields of research include the link between behavioral economics and food security and analysis of the factors and impact of technology adoption. 